IRSH 49 (2004), pp. 47-70 DOI: I0.I0I7/S002085900300I 366

(C) 2004 Internationaal Instituut voor Sociale Geschiedenis

\title{
Women, Protest, and Revolution: Soldiers' Wives in Russia During 1917\%
}

\author{
SARAH B A D OCK
}

Summary: This study explores the role and political impact of soldiers' wives in three Volga provinces of Russia: Nizhnii Novgorod, Kazan, and Tambov between February and October i9i7. Despite relatively low levels of formal organization, soldiers' wives made a significant mark on revolutionary politics at a local level. Common grievances, which centred on the inadequacy of state support in the context of rising food prices and shortages, were the defining feature of soldiers' wives as a group. Though they secured little direct representation in government, and did not affiliate with any political parties, they operated collectively to address their grievances, both in petitions and in public demonstrations. Their demands continued to escalate in I917, and the government was unable to cushion them from Russia's profound economic crisis. Soldiers' wives rejected both Soviet and provisional government leadership as a result, and their alienation contributed to the sense of political crisis that pervaded igi7.

\section{INTRODUCTION}

Soldiers' wives played one of the most prominent and best-known roles in the February revolution. Their demonstrations in Petrograd alongside other women on International Women's Day were the spark that lit the conflagration of revolution. ${ }^{\mathrm{I}}$ The toppling of the Tsarist regime in February I9I7 heralded an eight-month interregnum, during which the provisional government, a shifting coalition of liberals and moderate socialists, strove above all else to keep Russia in the war, and to avoid the

* This paper was first presented at the American Association for the Advancement of Slavic Studies conference, Washington DC, in November 200I, and a subsequent version was presented to the Birmingham University SIPS seminar in March 2002. Thanks to participants on these panels for their valuable comments, and particularly to Boris Kolonitskii, Mike Hickey, Rex Wade, and Christopher Read, and to the anonymous referees and editorial board of this journal. Thanks also to Graham Tan for his incisive remarks. The research for this paper was made possible by the generous support of a Leverhulme Trust study abroad studentship.

I. See S.A. Smith, "Petrograd in i917: The View from Below", in D. Kaiser (ed.), The Workers' Revolution in Russia in 1917: The View from Below (New York, 1987), p. 6r; R. McKean, St Petersburg Between the Revolutions: Workers and Revolutionaries, June 1907-February 1917 (New Haven, CT, 1990), pp. 460-470. 
civil conflict that loomed in an atmosphere of rising social, political, and economic crisis. The Bolsheviks' seizure of power in October I9I7 ended the provisional government's term in power, and marked the beginnings of civil war. The provisional government's fall was symptomatic of its inability to breach Russia's widening social polarization, and to meet the heightened expectations produced by the February revolution. Soldiers' wives (referred to throughout as soldatki) were an important societal group whose frustration escalated as their demands remained unmet in the course of 1917. Soldatki have been largely excluded from the master narrative of $1917 .^{2}$ There is a massive body of literature tackling the events of I917, but there has been a tendency in the historiography to focus on the activities of the organized and the "conscious", which privileges male forms of collective action at the expense of female. Where female activities have been considered, they have concentrated on women within clearly defined social groups. ${ }^{3}$ Soldatki encapsulated a diverse range of social groups, and present an opportunity to explore the participation of an amorphous group of women in revolutionary politics.

A bewildering array of interest groups formed as a result of the social dislocation caused by World War I. Refugees, orphans, prisoners of war, invalids, and the disabled all formed associations whose aim was primarily to defend their interests. ${ }^{4}$ With the exception of the soldiers themselves, soldatki comprised the largest and most vocal of these groups. This paper

2. Without doubt the most important work on soldatki is Emily E. Pyle's doctoral dissertation at the University of Chicago, which gives a detailed picture of soldiers' families' requests for aid and the implications for village social relations: E.E. Pyle, "Village Social Relations and the Reception of Soldiers' Family Aid Policies in Russia, I91 2-I92 I" (Ph.D. University of Chicago, 1997). Pyle does not, however, tackle the role of soldatki in 1917 in much detail, or investigate their role as political players. B.A. Engel, "Not by Bread Alone: Subsistence Riots in Russia during World War I", Journal of Modern History, 69 (1997), pp. 696-72 I, deals extensively with the role of soldatki in food disorders in the pre-revolutionary wartime period. B. Farnsworth, "The Soldatka: Folklore and Court Record", Slavic Review, 49 (I990), pp. 58-73, looks at the image and status of soldatki in pre-revolutionary Russia, with particular focus on the role of the soldatka in folk laments. A.G. Meyer, "The Impact of World War I on Russian Women's Lives", in B. Clements et al. (eds) Russia's Women: Accommodation, Resistance, Transformation (Berkeley, CA, I991), pp. 216-218, deals briefly with soldatki.

3. On Bolshevik women and women workers during 1917, see J. McDermid, and A. Hillyar, Midwives of the Revolution: Female Bolsheviks and Women Workers in 1917 (London, 1999). On the handful of women who served in the armed forces in 1917, see R. Abraham, "Mariia L. Bochkareva and the Russian Amazons of 1917", in L. Edmondson (ed.), Women and Society in Russia and the Soviet Union (Cambridge, I992), pp. I24-144. On peasant women in 1917, see B.B. Farnsworth, "Village Women Experience the Revolution", in A. Gleason, P. Kenez, and Richard Stites (eds), Bolshevik Culture. Experiment and Order in the Russian Revolution (Bloomington, IN, 1985), pp. $238-260$.

4. The crippled men who requested that they be asked to leave field hospitals politely, for example, conjures up a pathos-ridden picture; Gosudarstvennyi Arkhiv Nizhegorodskoi Oblast [hereafter GANO], f. I887, op. I, d. 20, p. 26; letter to the Nizhegorodskaia guberniia executive committee, from the invalids of Elkhovskii and Borisopol'skii volosts, 23 April 1917. 
seeks to explore the role and political impact of soldatki from February to October I9I7 in the guberniias of Kazan, Nizhnii Novgorod, and Tambov. It is argued that despite relatively low levels of formal organization, soldatki made a significant mark on revolutionary politics at the local level. Further, the moderate socialist leadership of local democratic organs was undermined by the disillusion of soldatki, and prefigured the more politically significant alienation of many workers and soldiers by October i9i7.

The regional focus of this study has been taken with the intention of presenting a more nuanced view of revolutionary events. Local and regional factors were crucial in determining the direction and character of social and political behaviour. Nizhnii Novgorod, Kazan, and Tambov guberniias are all situated in central European Russia, and bisected by the Volga river, Russia's primary artery. Nizhnii Novgorod guberniia was among Russia's most important industrial centres, with large metalworking factories employing some 70,000 workers. Tambov, on the other hand, was best known as a grain-producing province, and was considered to have been the Socialist Revolutionary Party's spiritual home. Kazan presents an entirely different profile; as the "gateway to Siberia", it formed a major trading and transport centre, and was very ethnically diverse. These three guberniias can be taken to loosely exemplify the principal aspects of agricultural and industrial European Russia. By focusing on soldatki actions in three guberniias, a view of revolutionary events can be developed which reflects regional specificity, and avoids crude generalization. ${ }^{6}$

5. Guberniia is the Russian equivalent of a province.

6. There have been a number of studies of revolutionary Russia in the last fifteen years that have concentrated on a specific geographical area. Mike Hickey's collection of articles and book chapters on Smolensk are among the most significant contributions made to our understanding of the revolution in the provinces. See M.C. Hickey, "Discourses of Public Identity and Liberalism in the February Revolution: Smolensk, Spring I917”, Russian Review, 55 (1996), pp. 6I 5-637; idem "Local Government and State Authority in the Provinces: Smolensk, FebruaryJune 1917" Slavic Review 55:4 (1996), pp. 863-88I; idem "Urban Zemliachestva and Rural Revolution; Petrograd and the Smolensk Countryside in 1917", Soviet and Post Soviet Review, 23 (1996), pp.r42-r6o; and idem "The Rise and Fall of Smolensk's Moderate Socialists: The Politics of Class and the Rhetoric of Crisis in 1917 ”, in D.J. Raleigh (ed.), Provincial Landscapes: Local Dimensions of Soviet Power, 1917-1953, (Pittsburgh, PA, 200I), pp. 14-35. The two chief monographs on revolutionary Russia in the provinces are O. Figes, Peasant Russia, Civil War: The Volga Countryside in Revolution (Oxford, 1989), and D. Raleigh, Revolution on the Volga: 1917 in Saratov (New York, I986). Other articles published more recently which reflect interest in regionally specific studies of revolutionary Russia include the work of Hugh Phillips on Tver, A. Khalid on Tashkent, and Aaron Retish on Viatka: H. Phillips, "A Bad Business': The February Revolution in Tver", Soviet and Post Soviet Review, 23 (1996), pp. I 20-I4I, and idem "The Heartland Turns Red: the Bolshevik Seizure of Power in Tver", Revolutionary Russia, I4 (200I), pp. I-2 I; A. Khalid, "Tashkent I9I7: Muslim Politics in Revolutionary Turkestan", Slavic Review, 55 (1996), pp. 270-296; A. Retish, "Creating Peasant Citizens: Rituals of Power, Rituals of Citizenship in Viatka Province, I917”, Revolutionary Russia, I6 (2003), pp. 47-67. 


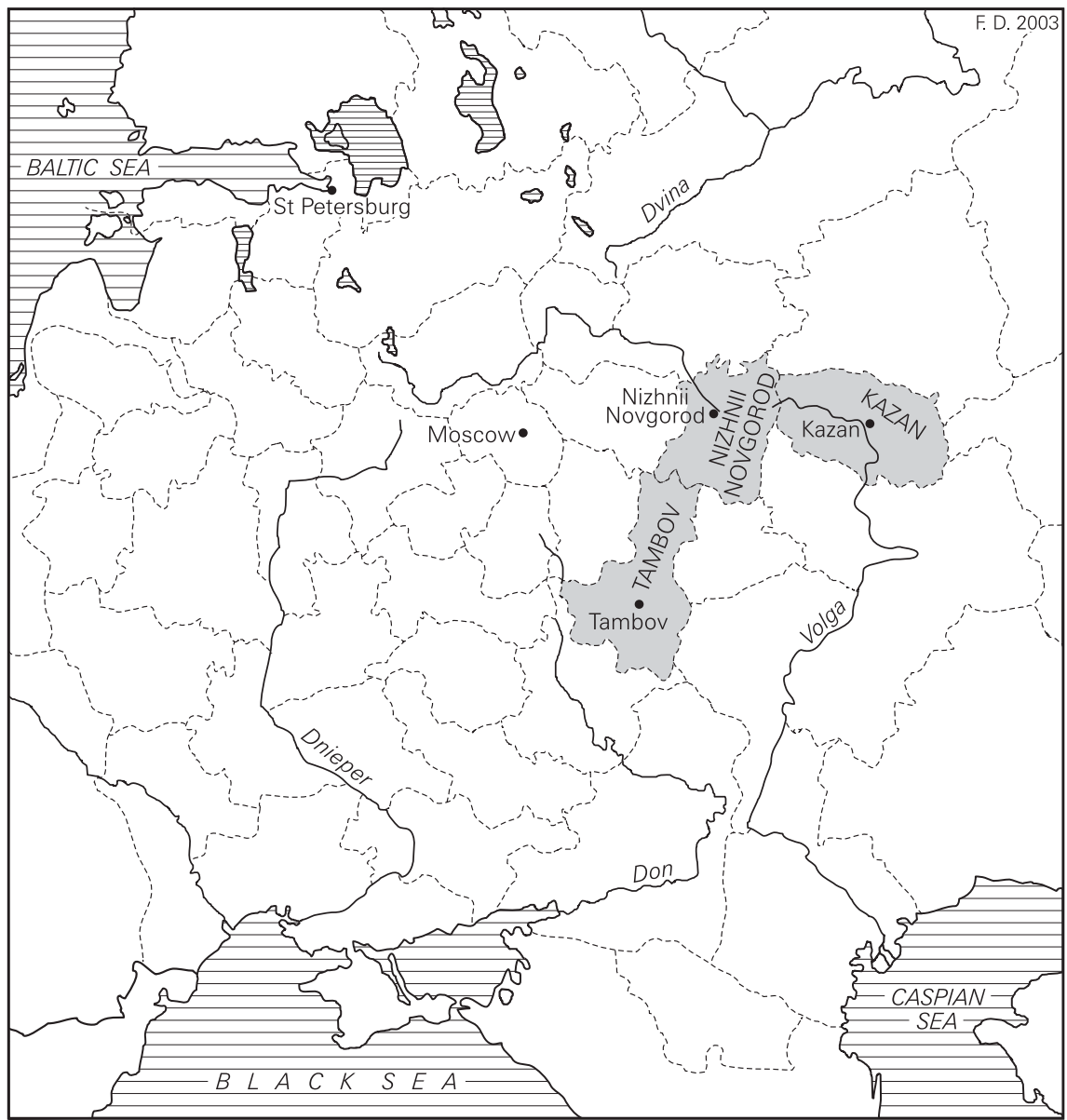

Figure I. The European Russian provinces.

The emergence of soldatki as a prominent social group was predicated by the mass mobilization following Russia's declaration of war on Germany on 4 August i9i4. Though the formal translation of soldatka was a soldier's wife, the term was often used more broadly in I9I7 to include other female dependents, and files of letters from soldatki often included correspondence from a range of family members. Soldatki had always been a significant minority group among married women, ${ }^{7}$ but mass mobilization caused soldatki numbers to swell dramatically.

7. Farnsworth, "The Soldatka: Folklore and Court Record", p. 71. 
Estimates of the numbers of men mobilized during World War I vary, but Wildman suggests a total mobilization figure of 15.3 million. ${ }^{8}$ One can correspondingly estimate soldatki numbers at around $\mathrm{I} 4$ million. The prominence of the category soldatka in appeals and declarations indicates that it was chosen by a range of women as a social definition. All those defining themselves as soldatki had other social categorizations that they could subscribe to, and some used a double barrel to describe themselves, such as worker-soldatka or peasant-soldatka.

\section{SOLDATKI GRIEVANCES}

Common grievances provided the central defining feature for soldatki as a group. The most widely expressed demand was for an increase in the allowance that was provided to the soldiers' families. This was often submitted by soldatki from a particular village or volost jointly. The dramatic increase of price on products of first necessity, alongside rampant inflation, left soldatki who relied on the state allowance for subsistence in an unenviable position of impoverishment, something commented upon by a range of sources. Nizhegorodskaia guberniia's executive committee, for example, commented on the "scandalous distress" (vopiushchaia nuzbda) many soldatki were in, ${ }^{9}$ while a writer in a Kazan newspaper commented that some soldatki were "utterly destitute" (gol' perekatnaia). ${ }^{10}$ This state of crisis escalated in the course of 1917. Material need was perhaps the deciding factor in their drive to organize themselves collectively. Demands for supply of food products tended to reflect the provisions situation in the guberniias. Nizhegorodskaia guberniia faced a provisions crisis that threatened famine from the outset of $1917 .{ }^{I I}$ As one might expect, demands there focused on the supply of sufficient bread. In Kazan guberniia, which produced grain for export, grain shortages were not so widespread, yet demands for provisions were just as vociferous, and encompassed, instead of cries for the staple of life, demands for sugar and white flour. ${ }^{\mathrm{I}}$ Where there was a shortage, even if, like sugar, it did not threaten life, this shortage became a major issue of the day, and took on

8. A. Wildman, The End of the Russian Imperial Army: The Old Army and the Soldiers' Revolt (March-April 1917) (Princeton, NJ, I980), p. 52. Meyendorff's estimate was close to this, at I 5.123 million; A. Meyendorff, S. Kohn, The Cost of the War to Russia (New Haven, CT, 1932), p. 16.

9. GANO, f. I 887 , op. I, d. 22, 1. 23.

I0. Izvestiia Kazanskago voenno-okruzhnago komiteta, no. I3, 4 June I917. p. I.

I I. GANO, f. 2603 , op. I, d. 2, p. 234; from the fond of Gorbatovskii nezd executive committee, delo holding protocols of the volost executive committees.

I2. Kazanskaia rabochaia gazeta, no. 31, I8 May 1917, p. 3. 
equivalent or even greater force than demands for bread in a hungry guberniia. ${ }^{13}$

Other categories of complaint were requests for free, or subsidized fuel, refusal or inability to pay taxes, about nonpayment of state allowance, about the status of common-law wives, shortage of housing, landlord attempts to evict soldatki, and requests for husbands, fathers, and sons to be given leave in order to help with fieldwork. ${ }^{14}$ There were also more specific personal grievances. The Kazan guberniia Soviet of peasants' deputies, for example, asked the Voskresenskii volost ${ }^{15}$ committee to intercede on behalf of the soldatka Olga Makarevna Egorova, of Gorkii village, Voskresenskii volost, whose father-in-law, Semion Egorov, had thrown her out of her house without compensation, forcing her and her little son to live with strangers. ${ }^{16}$ Egorova's complaint demonstrates the willingness of soldatki to bring a host of grievances to the attention of the Soviets.

The tsarist government had made some attempt to define the category soldatka more clearly, in order to establish who was to be eligible for state support. The resulting law, passed on 25 June 19I2, was ambiguous. ${ }^{17}$ All wives and children of soldiers called into active service were theoretically eligible for a state allowance, which was administered as a monetary sum. Common-law wives and their children were not, however, included in this remit, which was a significant omission. ${ }^{18}$ The provisional government was

I3. This issue is commented upon at length in B. Engel, "Not by Bread Alone”, esp. pp. 7i 8720. She comments that such demands for "non-essential products" might be interpreted as signifying a rise in the standards of living and expectations of the lower-class population, or that it might, on the contrary, indicate that sugar and tea were being used as a replacement for more substantial subsistence foods. See also S. Mintz, Sweetness and Power: The Place of Sugar in Modern History (New York, 1985), p. I49. There were frantic cries across the spectrum of Kazan newspapers regarding the shortages of sugar, white flour, and tea.

I4. For just a few examples of these complaints, see GANO, f. 2603, op. I, d. 2; fond of Gorbatovskii nezd executive committee, delo of protocols of volost executive committees, esp. pp. 169, 199, 200, 217.

I5. Volost was the smallest administrative division in tsarist Russia.

I6. Natsionalnyi Arkhiv Respubliki Tatarstan [hereafter, NART], f. 983, op. I, d. 23, p. 235 . This reflects, as much as anything, the degree of minutiae into which the Soviet was drawn; their response to this plea, and innumerable others, many of a personal nature, are all carefully documented.

17. See Pyle, "Village Social Relations", ch. 2, pp. 105-175, for an assessment of the evolution of the I9I 2 law, and particularly pp. I II-I 54 , for a summary of said law.

I8. GANO, f. IIоI, op. I, d. 23, p. 749; letter from the Soviet of soldiers' deputies, Nizhegorodskaia garrison, dated 23 March 1917, to the Nizhegorodskaia uezd trusteeship for the assistance of soldiers' families, asking whether common-law soldiers' wives have the right to receive the state provisions grant. The trusteeship answered on reverse side on 27 March 1917, and quoted the law of is June I9I 2 about the right of all lower military members' families, including common-law wives and offspring, to receive state allowances. This is a good example of the ambiguity of the I9I 2 law, which was here interpreted as including common-law wives in its remit. 
put under pressure to revise this statute, and in June I9I7 it broadened the criteria for eligibility to include common-law wives, foster children and step-parents. ${ }^{19}$ This broadening of the category, along with an increase in the number of applications for support, increased the already enormous financial burden soldatki support imposed on the state. The number of recipients of the state allowance increased from 25 million in 1916 to 36 million by September 191 $7 .{ }^{20}$ From the outbreak of the war until January I917, aid to soldiers' families cost around 2 billion roubles, which was some 7 per cent of Russia's total military expenditure. ${ }^{2 \mathrm{I}}$ Between February and October 1917, I.46 billion roubles were spent on allowances, which accounted for nearly i I per cent of military expenditure.

This vast expenditure, and its effective allocation, was an enormous burden on Russia's overstrained economy and administration. The law of I9I 2 had established a network of committees to minister to soldatki needs, but even before the administrative and financial disarray that resulted from the February revolution, the state was unable to meet soldatki demands. The "Nizhegorodskaia guberniia committee for the assistance of sick and wounded military and the families of drafted men" met on I $_{3}$ February I9I7 to discuss a potential increase in the allotment of money for the needs of families of drafted men. The chair of the meeting, P.A. Demidov, ${ }^{22}$ pointed out that the debt incurred by the guberniia zemstvo $\mathrm{O}^{23}$ in providing assistance to needy families had risen to 650,000 roubles. ${ }^{24}$ The meeting concluded that:

The committees simply cannot fulfil their initially stated principle, to show assistance to all families requesting help, and the role of the committees now must be to show assistance to those groups of the population who are in the most unfavourable situations, for example those excluded from state allowance (common law wives, families situated in active service) [...] Monetary assistance must have a place only in exceptional cases, since the population are needy, in the main, not for money, but for products, and in relation to this very question, both $u e z d^{25}$ and guberniia committees are not in a position to assist. Any increase of money to the nezd organizations must be looked over thoroughly, as experience

I9. R. Browder and A.F. Kerensky (eds), The Russian Provisional Government: Documents, 3 vols (Stanford, CA, I96I), vol. I, pp. 800-801, doc. 699, “The Extension of Support for Soldiers' Families, 22 June 1917".

20. Rossiia v mirovoi voine, I9I4-I9I8 goda (v tsifrakh) (Moscow, I925), table 4I, p. 50.

2 I. A.L. Sidorov, Finansovoi polozhenie Rossii v godi pervoi mirovoi voini (19I4-19I7) (Moscow, I960), pp. 108-I20.

22. Demidov was head of the zemstvo and after the February revolution served as guberniia commissar for around three months.

23. Zemstvo was an elective district council. They were established in I 864 , and existed at uezd and guberniia levels.

24. GANO, f. 2603, op. I, d. 2, p. 234; from the fond of Gorbatovskii uezd Executive Committee, delo holding protocols of the volost executive committees.

25. Administrative unit, smaller than a guberniia and bigger than a volost. 
has shown that these uezd committees have not been very active locally, because their organization suffers from grave insufficiencies. ${ }^{26}$

These committees continued to function in 1917 , but were supplemented by the efforts of the Soviets, provisional government organizations, and ad hoc committees. This amalgam of organizations bearing some responsibility for administering aid to soldatki only contributed to the administrative confusion and inefficiency that was a theme of soldatki complaints. The main difficulty for the state in administering aid to the soldatki was not administrative confusion, however, but financial crisis. ${ }^{27}$ Administrative bodies repeatedly stated that they would like to help soldatki more, but had no funds available. Problems were compounded by the grain situation, which deteriorated in the course of 1917. Supply problems were regional or even local in nature, but the lack of an effective transport infrastructure meant that some areas faced hunger or even starvation by the autumn of I917, even where neighbouring provinces enjoyed grain surpluses. In Nizhegorodskaia guberniia, there were chronic grain shortages from the outset of $1917 .{ }^{28}$ Some areas of Kazan guberniia also faced hunger by the autumn of 1917, even though it was bordered by grain-rich Tambov.

\section{THE NEW ORDER}

The diversity and local specificity of the organizations that developed in the wake of the tsarist administration's collapse are bewildering in their scope. The provisional government sought to establish a structure of local government, headed by the guberniia commissar and the uezd commissars, a rank given to uezd zemstvo chairmen. ${ }^{29}$ Various public committees, commonly named "committees of public safety" formed in the immediate aftermath of revolution, often encompassing the most experienced administrators of the locality. These committees in some places formed a nucleus of support for the activities of the guberniia and uezd commissars. The Soviets of soldiers', workers', and peasants' deputies evolved autonomously..$^{30}$ All these myriad forms of local government shared the

26. GANO, f. 2603 , op. I, d. 2, p. 234.

27. GANO, f. 27, op. I, d. 3, 1. 39; from Duma records, I6 September I 917.

28. For a discussion of the provisions crisis in Nizhnii Novgorod, see S. Badcock, "Support for the Socialist Revolutionary Party in 1917, with a Case Study of Events in Nizhegorodskaia guberniia" (Ph.D., University of Durham, 2000), ch. 4, pp. I36-I39.

29. Browder and Kerensky, The Russian Provisional Government, vol. I, p. 243, doc. 219; circular from the Minister of the Interior, 5 March 1917.

30. Generally speaking, the Soviets of workers' and soldiers' deputies met together, or had a joint executive committee (as in Nizhnii Novgorod), but the Soviet of peasants' deputies tended to retain independence, even if it participated in joint Soviet meetings, or publications (as in Tambov). 
aspiration to represent and defend all sectors of the community. In the case of the Soviet, this representation and defence was targeted specifically at all toiling and impoverished (trudiashchiisia i obezdolennyi) people.

Whilst the February revolution compounded the administrative and financial difficulties of administering aid to soldatki, it simultaneously heightened expectations of government, heralding significant changes in both the mechanics and in popular expectations of local administration. The rhetoric of revolution promised equality, freedom, and justice. Soldatki clearly took this new rhetoric on board, and expected the new democratic administration's lofty ideals to translate into real improvements in soldatki conditions. Democratization was popularized across Russian administration at all levels, from the lowliest volost committee to the guberniia head. The forming of interest groups was commonplace in 1917, whether these were based on occupation, political affiliation, nationality, gender, or other shared interests. Soldatki, as a group sharing common grievances, formed a powerful if amorphous group that could place its requests and complaints to the administration at a level and a persistency that was not possible prior to the revolution.

Soldatki secured little direct representation in the myriad forms of government that were established in the wake of the February revolution. This is a reflection of the absence of women from all levels of administration, from the village $s k h o d^{3 \mathrm{I}}$ up to delegates for the Constituent Assembly. ${ }^{32}$ At lower levels of organization, on volost and uezd executive committees, the delegates were almost exclusively male. If a woman did have a place, it was usually the place allotted to a teachers' representative. 33 A cursory examination of lists of Soviet deputies demonstrates that women were very rarely elected as deputies to the Soviet, and correspondingly very rarely participated in the Soviet's higher committees. The reasons for this are based on the domination of the

3r. Skhod was a village gathering or assembly, which often made communal decisions.

32. Of the ninety-two Socialist Revolutionary party candidates to the Constituent Assembly from the guberniias of Nizhegorodskaia, Tambov, Penza, Kazan, and Simbirsk, only three were women. Ekaterina Breshkovskaia, not so much a woman as a national icon, stood as candidate for the Simbirsk PSR Elder-defencists' list. Victor Chernov's wife, A.N. Chernova Sletova, stood alongside her husband on the Tambov list. The only unknown woman among these three was Vera F. Vasileva, a worker from the Alafuzovskii factory in Kazan and a member of the factory committee there.

33. Volost and uezd executive committees in Nizhegorodskaia guberniia sent lists of their members to the guberniia commissar, and these lists are almost exclusively male, with the exception of places where a place was reserved for the regional teachers; this place was often taken by a woman. For examples of this phenomenon, see GANO, f. 8 I 5 , fond of Semenovskii uezd committee of the provisional government, d. I6, "List of Elected Representatives and Protocols of volost zemstvo Meetings and Electoral Commission, 30 June- I 2 December"; d. I7, "Copies of the Protocols, and Lists of Members, of the volost Committees", esp. pp. 35, 56; d. I 8, "Copy of Protocols about the Election of Representatives and Committee Members", esp.p 8; d. 21, "Iamnovskii volost Executive Committee", esp. p. 3. 
democratization process, particularly at grassroots level, by local working men and soldiers. Women were only given the right to vote, and the opportunity to serve in elected offices, in summer 1917, though the informal voting procedures in many Soviet bodies allowed female participation from the outset of the revolution. Russia's democratization process explicitly appealed to the electorate in 1917, and the electorate responded by returning almost entirely male representation on the democratized bodies of 1917. ${ }^{34}$ This comment on women's participation in public life, from a report compiled by the provincial section of the temporary committee of the state Duma in April, is telling:

There was opposition from workers and peasants to the participation of women in elections. Nothing was said to women, and in places not only did they not participate in the building of public life, but often they also didn't know about the rights that they had received in the course of the revolution. When delegates tried to clarify the situation they said that up until now they didn't know anything and thanks to this they knew nothing. Greeting similar conversations, the peasants with resentment observed, "You stir up our women, then they will not go into the shafts." And there are almost no cases of women being elected in the villages. 35

There were even specific cases of soldatki being refused the right to participate in volost administration. A complaint was received from thirteen soldatki of Nizhnii Novgorod guberniia that a deputy of their volost administration, in answer to their question of why a soldatka deputy had not been allowed to participate, answered: "Obviously, it's unnecessary to allow riff-raff (svolochi) into the workplace, and it is better to close the doors to keep such riff-raff out." 36

\section{SOLDATKI ORGANIZATION AND ACTIONS}

The non-participation of women in the newly democratized local government structures left soldatki, a large and well-motivated group, on the margins of power. They were to have significant impact on the course of local government, but their participation was from the periphery, and not from the heart of local government. Soldatki formed autonomous organizations that did not work strictly within the sphere encompassed by the Soviets, but overlapped with it. There was a union of soldatki formed at

34. See S. Badcock, “'We're for the Muzhiks' Party!': Peasant Support for the Socialist Revolutionary Party during 1917", Europe Asia Studies, 53 (2001), pp. I43-I46.

35. RGIA, f. I 278 , op. I, d. 4, p. 248 ; report of the provincial section of the temporary committee of the state Duma.

36. GANO, f. I IоI, op. I, d. 23, p. 363; complaint addressed to the Soviet of soldiers' and workers' deputies, from thirteen soldatki of Goroulevskii volost, headed by Varvara Borynina, 20 April 1917. 
national level by the Petrograd Soviet in June I $917,{ }^{37}$ but no reference was made to any central soldatki organization in Kazan, Nizhnii Novgorod, or Tambov. The alliances of soldatki that formed in the guberniias of Nizhnii Novgorod, Kazan, and Tambov shared common grievances within the context of local conditions, but developed in quite distinct directions, reflecting the importance of individual leadership in forming these organizations. Unfortunately, the sources make almost no reference to the individuals who were prominent in the soldatki organizations, making impossible any more detailed assessment of soldatki leaders. It is, however, possible to present a broader picture of soldatki organization and leadership.

At an early stage of 1917, the Nizhegorodskaia guberniia Soviet of workers and soldiers' deputies was careful to embrace the soldatki in its remit. The women were invited to send a representative to the Soviet's meetings. Though the demands of the soldatki in Nizhegorodskaia guberniia were numerous, and acknowledged across all levels of administration, they did not form their own autonomous association, and did not put any external pressure on the Soviet. The Soviet's careful embracing of the soldatki at an early stage may well have given the soldatki a sufficient degree of public outlet, and thus averted the build-up of sufficient discontent required for the soldatki to operate independently of the Soviet. Their lack of vocal representation in public forums reflects a lack of concerted leadership for the Nizhnii soldatki.

In Tambov too, soldatki did not themselves form a recognized body, though in August a union of soldatki was formed by the Soviet. ${ }^{38}$ This was a retrospective measure aimed at restraining and containing the Tambov soldatki movement, which from the very outset of revolution formed a stormy and volatile force in local politics. ${ }^{39}$ Despite their high level of activity, the Tambov soldatki apparently lacked internal leadership. In the general meeting of soldatki organized by the Soviet on 8 October 1917, both president and secretary of the meeting were men, ${ }^{\circ}$ which would indicate that even by autumn I917, the soldatki had not found leadership from within its group. This was certainly the case earlier in 1917. A soldatki meeting was organized on 2I March by two renegade soldiers,

37. See E.E. Pyle, "Village Social Relations", p. 293.

38. Izvestiia Tambovskago soveta rabochikh, krestianskikh $i$ soldatskikh deputatov, no. I 20, 25 August I9I7, p. 4; report on the general meeting of the Soviet of workers' and soldiers' deputies, 5 August 1917.

39. The Soviet-inspired soldatki union was a rather more sedate affair. In a meeting as late as October, the meeting attacked soldiers not fulfilling their duties at the front, and offered its full support for the provisional government; Izvestiia sovietov rabochikh I soldatskikh deputatov, no. 52, 8 October 1917, p. 2 (published in Nizhnii Novgorod). Such views were not compatible with the fierce radicalism of the Tambov soldatki.

40. Izvestiia Tambovskago soveta rabochikh, krestianskikh $i$ soldatskikh deputatov, no. I47, 17 October 1917, pp. 2-3. 
Shvedov and Krupenin, where speeches of "a rousing nature" were heard. In its meeting on 22 March, the Soviet of workers and soldiers' deputies denounced Shvedov and Krupenin, and appealed to the population that: "The speeches of these private individuals were not from any direct organization and were to be treated with great caution." 4 I

The soldatki did not, however, heed the warnings of the presidium regarding the two soldiers, and on 25 March there was a further meeting of soldatki, led by Krupenin and Shvedov. In this the soldatki specifically rejected Soviet leadership. Three delegates from the Soviet of workers' and soldiers' deputies appealed to the soldatki, and rhetorically asked them whether it was better to trust separate individuals or organizations. The soldatki, however, supported Krupenin and Shvedov, and gave them red armbands to wear as a sign of their trust. The Soviet's representatives, having been so demonstratively shunned, left the meeting. Krupenin and Shvedov were apparently unable to call the Tambov soldatki to order. A reporter scathingly described the chaos of the meeting:

The meeting's leaders went on to discuss current questions, and the distribution of roo० roubles allocated by the public committee. There wasn't just one meeting, but several, as different questions were discussed in different corners. It was impossible to come to any sort of decision. It was funny; Shvedov shouted to comrade soldatki that they should address their delegates for the distribution of the rooo roubles. But the soldatki just stayed in their corners and tried to outshout each other. It was possible only to establish that those situated closer to the president declared that the $\mathrm{I}, 000$ roubles would be sent to the front. It has to be added here that the $\mathrm{I}, 000$ roubles was in the hands of the public committee and not with Shvedov and Krupenin; the money would only be transferred to some sort of organization and not to separate individuals. There was around three hours of pointless chatter before the soldatki dispersed to their homes. In the evening, soldatki delegates came to the Soviet of workers', and soldiers', deputies and asked for a clarification of what they should now do, as Shvedov and Krupenin could not give them anything but words. ${ }^{42}$

The soldatki of Kazan guberniia, in contrast to those in Tambov and Nizhnii Novgorod, had internal leaders, who from early stages organized and formed the women's movement. A formal association was created at the beginning of April, predating the central soldatki organization formed in Petrograd, with the aim to improve soldatki conditions of life. ${ }^{43} \mathrm{~A}$ reflection of their self-awareness as a group was the formal photograph taken of the committee members together. The well dressed, educatedlooking women in the photograph give a rare indication of the social character of these organic soldatki leaders. Their dress and demeanour

4I. Tambovskii zemskii vestnik, no. 67, 24 March 1917, pp. 2-3.

42. Ibid., no. 69, 28 March I917, p. 3.

43. Kazanskaia rabochaia gazeta, no. 30, I7 May 1917, p. 3. 


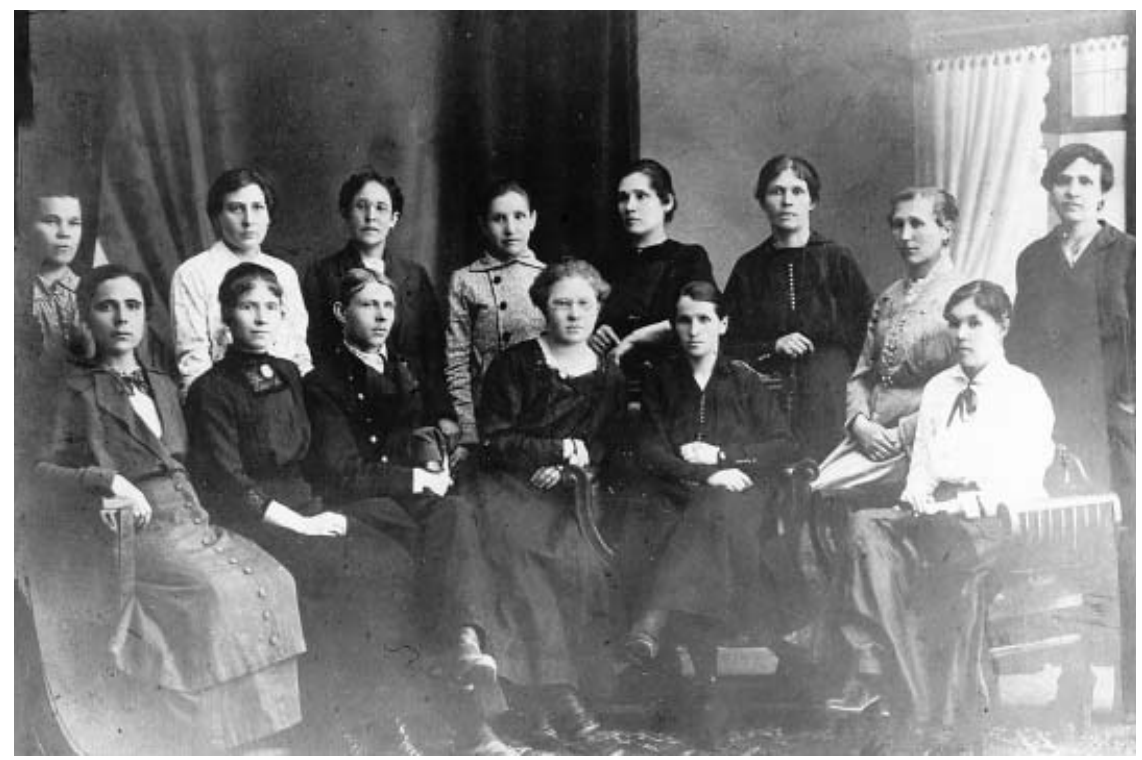

Figure 2. Group of active soldatki, Kazan, I917. These women are respectably dressed, and two are wearing spectacles. They give the impression of being well-to-do professional women. The young man, third on the left, is unidentified, but is probably a Soviet delegate who assisted in the organization of the Kazan soldatki union.

Archives of the National Museum of the Republic of Tatarstan; Kazan; used with permission.

suggest that they were professional women, like teachers or clerks. The Kazan soldatki union was initiated by the women themselves, and not at the behest of the Soviet, as in Tambov and Nizhnii Novgorod. The level of soldatki organization in Kazan was accordingly at a much higher level. At their meeting in May, red flags were prepared, inscribed with "bread" and "increase the allowance for soldatki". ${ }^{44}$ The secretary of the union, Zinaida Matveevna Antonova, stood as a candidate for the Town Duma.45 Despite this higher level of executive organization, a commentator remarked that: "The administration could not, however, restrain the poor, hungry, barely conscious women to whom it seemed that no measures had been taken for improvement of their situation." ${ }^{6}$ This comment must be read with caution; it may reflect the prejudices of the Soviet reporter, and a desire to belittle soldatki organization. It does however suggest that the leaders of the soldatki were absolutely distinct from the soldatki themselves, confirming the impression from their photograph of educated 
professionals, far removed from the peasants and workers that made up the mass of soldatki. It also indicates that though the Kazan soldatki had internal leaders and administrators, this leadership was far more moderate and conventional than the majority of the Kazan soldatki, and was unable to restrain its "followers".

Soldatki operated on a number of levels in voicing their grievances, and attempting to extract concessions from the authorities. They submitted written statements, participated in administrative organizations, and acted autonomously, outside these established organizations, in order to attract public support for their pleas, and to put direct pressure on the administration. A common feature of the presentation of these grievances was the enthusiasm of the women to present their grievances collectively, rather than individually. ${ }^{47}$ The majority of soldatki complaints and requests were addressed to the Soviet of soldiers' deputies, and not to the guberniia or uezd commissars. This is a telling reflection of the balance of power in the guberniias and of the prestige of the Soviets. The most common forms of address were written petitions, complaints, or requests, submitted both independently and collectively. A large collection of soldatki letters of grievance has been preserved in the Nizhnii Novgorod State Archive. ${ }^{8}$ Some of these were written by the women themselves, and others composed on their behalf by a scribe or other literate person. In a number of cases soldiers interceded personally on behalf of their wives, both singly and collectively. At a general meeting of the $183 \mathrm{rd}$ reserve infantry regiment, on 20 April, it was decreed after fierce discussion:

[...] to commandeer a delegate and send a telegram to the war minister and to the Soviet of soldiers' deputies in Petrograd, in order quickly to clarify the question about increase in soldatki pay, allowance for their families and pensions for invalids, declaring in all seriousness the reasons motivating this step. ${ }^{49}$

The collective action taken by soldatki shows that they found sufficient common ground, in the urgency of their pleas and in their lack of direct representation in government, to act together. There were instances where joint soldatki action was grouped by village or volost. In certain cases it was a response to a specific problem. The women of one volost used a preprinted form to appeal about the non-payment of their allowances. Their husbands had been taken prisoner voluntarily, which classified them as deserters, thus leaving their families ineligible for state support. This

47. This may be a reflection of the tsarist policy actively to encourage the collective submission of petitions; Pyle, "Village Social Relations", p. I 86.

48. GANO, f. I IоI, op. I, d. 23; a collection of 929 letters, mostly from soldiers' families, and a few from wounded soldiers. Many of these letters were from illiterate women, and were written on their behalf by a scribe. Many more were barely legible.

49. GANO, f. I Iо I, op. I, d. 5, protocols of the Soviet of soldiers' deputies, I83rd infantry reserve regiment, p. 9. 
excerpt from Daria Ivanovna Saiunovna's letter illustrates the powerless position of these women:

My husband, Ivan Vasilivech Saiunov of the 48th Siberian regiment, was taken prisoner and is still imprisoned. Since his capture I have not received allowance for his family, of myself and his two children aged five and four. [...] the administration declared the last time I was given allowance that my husband gave himself over voluntarily as a prisoner and that is why I will receive no further allowance. I request to the Soviet of soldiers' deputies to come to my family's aid, since I am not guilty of anything and must struggle with needy children in such difficult and hungry times, I don't actually know if my husband is guilty, and I cannot say anything about his motivations in handing himself over, but if he is guilty, then why are his innocent children going hungry in a state of poverty $[\ldots] .5^{50}$

The complaints submitted, even when individually written, rather than a mass complaint or a pre-printed form, were often very formulaic in their style. As in the pre-revolutionary period, petitioners invoked a combination of formal rules and moral principles in support of their claims. ${ }^{\text {II }}$ The new expectations and rhetoric of revolution did have a significant impact on the form of these complaints. Petitioners frequently referred to their rights, rather than just relying on moral principles and charity. It was usual for the soldatka to mention, in order, herself, the names and ages of her children, and the names and ages of dependent elderly parents (those mentioned were almost always the birth parents of the soldier, and not his wife). Nadezhda Grigorevna Fel'man's appeal to the Soviet of soldiers' deputies, dated I9 May I9I7, is typical in form:

I humbly request that you consider carefully the situation of my family as stated below, and do not refuse my request. I am a weak, sick woman. My son Vladimir was taken into military service, and he is my sole source of nourishment and sustenance. I petitioned about the receipt of state allowance but was always refused. I have with me my daughter Maria aged nine, and as a result of poor health, and malnourishment through the rising cost of living, I am not able to work and feed myself. In this grave situation, I do not receive allowance. ${ }^{52}$

The request of Sophia Fedorovna Patkin to the Soviet of soldiers and workers' deputies is also typical. She was a peasant-soldatka from Kostianskii volost, Arzamasskii uezd, Nizhegorodskaia guberniia:

50. GANO, f. IIOI, op. I, d. 23, p. I73.

51. See Emily E. Pyle, "Peasant Strategies for Obtaining State Aid: A Study of Petitions During World War I", Histoire russe, 24 (1997), pp. 4I-64, for a discussion of pre-revolutionary peasant strategies to obtain state aid, and the petitioners' tendency to ask in terms of charity, rather than "rights".

52. GANO, f. IIоI, op. I, d. 23, p. 574 . 
I, the undersigned Sophia Fedorovna Patkin, twenty-one years old, with a little two-year-old boy child in my arms, humbly ask the Soviet of workers' and soldiers' deputies to investigate the conditions of my situation. My husband Feodor Filipovich Patkin was taken into active military service on I 8 June I9 I 5 , and so already for two years while he served I was left with a little child without any means for subsistence, and taking into account the rising prices and generally difficult situation, since I am still bound to my child. 53

A relatively common phenomenon in these complaints was the direct relation presented by the soldatki of what they were giving to the state, and what they expected in return. The rhetoric of complaint blurred into the reality of their situation - they had given their sons and their husbands to the national interest, and their contribution to the state was the blood of their kin. The justification given to the Nizhegorodskii uezd commissar by soldatki for their non-payment of taxes was that since their husbands were away spilling their blood, the wives would not give any money to the state. ${ }^{54}$ An appeal from the Kazan soldatki organization directly declared to women that they had lost their sons and brothers and husbands to the war, and now were compelled to defend their own families, who faced want and hunger.55 The language of the battlefield was directly employed in the domestic sphere.

The soldatki of Kazan and Tambov did not restrict themselves to the language of the battlefield. Their demands were also presented directly to the guberniia administration, sometimes in violent or threatening forms. The direct action of soldatki during I9I7 was in some respects a continuation of the food riots seen throughout the war period in Russia, which were often led by women. ${ }^{56}$ It also resonates with descriptions of peasant women's protest during the late 1920's and early I9305. ${ }^{57}$ From the very beginnings of revolution, the Tambov soldatki formed an intimidating presence in the guberniia, and directly threatened the administration of the town. Initially, the public committee that formed in the wake of the revolution bore the brunt of their anger. A meeting of the Tambov Town

53. GANO, f. I IоI, op. I, d. 23, p. 771; undated.

54. GANO, f. I882, op. I, d. 45, 1. 288. Report from Nizhegorodskii uezd commissar, Is September 1917 .

55. Printed in Rabocbii, no. I4, 25 (12) May 1917. Rabocbii was the organ of the Bolshevik organization in Kazan town. Note that soldatki obligations regarding taxation were regarded as ambiguous anyway; Pyle, "Village Social Relations", pp. 21 5-2 I6.

56. See B. Engel, "Not by Bread Alone: Subsistence Riots in Russia During World War I", Journal of Modern History, 69 (1997), pp. 696-721.

57. Lynn Viola's work on women's protests during collectivization show that they shared many features of soldatki protests and the ways in which such protests were reported. See L. Viola, "Bab'i bunty and Peasants Women's Protest during Collectivisation", Russian Review, 45 (I986), pp. 23-42, esp. p. 33 regarding the reporting of women's protests, and pp. $38-39$ on the well-organized nature of some women's protest, and its utilization as a response to specific grievances. 
$D u m a^{5}$ on 20 March, which included Soviet representatives, dealt mainly with the question of soldatki:

Soldatki had already declared lack of faith in the public committee. This mistrust was to have serious implications. Around 500 soldatki gathered and went to the public committee, demanding the key for the provisions storerooms. All explanations and requests had no effect. The soldatki stood their ground and declared that the public committee had embezzled all money for the soldatki, that fuel and means had been distributed unfairly and so on and so on. The soldatki did not of course provide any concrete accusations, as they couldn't. All it came to was noise and shouting. A representative of the committee gave the key to a representative of the Soviet of workers and soldiers' deputies, who had been commandeered for the pacification of the soldatki. The soldatki meeting, at cafe number one, was very noisy. The soldatki continued to insult members of the public committee, calling them thieves and other such things. At last after great effort twenty delegates were elected and they were commissioned to carry out a revision of the public committee. 59

This fracas set the tone for future soldatki relations with both the town committees and later the Soviet in Tambov. This atmosphere of open hostility was also witnessed in Kazan, where soldatki consistently undermined and challenged decisions made by both town committees and the Soviet. At a meeting held by the Kazan soldatki union in May, demands were voiced for provision of sugar and white flour, and for the increase of their allowance above the already agreed increase from 3 to 7 roubles, up to a new sum of 20 roubles. The meeting's participants were counselled by one of the orators to go to the Soviet to lay down their demands, since the Soviet "defended all toiling and impoverished people" ${ }^{60}$ At this, the entire meeting marched to the gates of the palace where the Soviet was in session. The besieged Soviet sent a representative to pacify the women, and entreated them to elect ten representatives to come into the Soviet building and clarify their situation. ${ }^{61}$ The Sovietsponsored newspaper afterwards reported that the women's anger was misdirected - they had received no response from the town administration to their pleas because they had provided no correspondence address, and their representative had not been present when the Soviet discussed their case. The Soviet clarified to the women's representatives that telegrams had been sent to the war minister about the plight of soldatki, and invited their representatives to the next Soviet meeting, where soldatki grievances would be discussed. Whilst this was sufficient to diffuse the rising anger of the assembled women, it did not avert the women's march around the

58. Duma - a town council, elected on a restricted franchise, which existed in medium-sized and large towns. In 1917, they were re-elected on democratic principles.

59. Tambovskii zemskii vestnik, no. 66, 23 March I917, p. 3.

60. Kazanskaia rabochaia gazeta, no. 31, I8 May I917, p. 3 .

6I. Ibid., no. 31, I8 May 1917, p. 3. 
town, complete with banners and placards, demanding that their complaints be heard. ${ }^{62}$ Such public demonstration of dissatisfaction with the Soviet's actions in defending working people was potentially injurious to the Soviet's reputation.

The following week the Kazan Soviet held a public session in the town theatre, in which soldatki issues were discussed. The decision to hold a public session is significant, as it reflects the level of public concern and mistrust the soldatki issue was raising, and the Soviet's concern to address the grievances of its chosen constituents. The choice of a theatre as the meeting's location, whilst no doubt a practical choice given the number of delegates and audience, was apt as the meeting developed into something of a public spectacle. A report of the meeting, written by an unnamed Soviet member and published in Kazanskaia rabochaia gazeta, gave an unsettling account of the stormy meeting. He declared, "It is difficult and even useless to give a detailed report on the meeting." ${ }_{3}$ Soviet deputies, the supposed chosen representatives of the people (narod), were challenged and shouted down, most vocally by the soldatki and their supporters:

Discussion of the soldatki question went on for more than four hours and by the end there was a storm even above the discussion. Amid worrying noise, shouts both from the public and from the Soviet members, the meeting was closed at one in the morning. In the Soviet there was no one who did not feel for the condition of the soldatki, and the speeches of the soldatki wrenched blood from the hearts of all that listened. But it was impossible for soldatki needs to be satisfied, because neither the state nor the Soviet had the means. The Soviet decided to do all that it could, but only what it could [...] attempts were made at heavy blows on the Soviet; it was even said that the Soviet had increased means for officers' wives but not for soldatki. There has never been discussion in the Soviet about officers' wives. It was unconscious force against the Soviet, rising anarchism and worrying provocation. ${ }^{64}$

This recalls the description of the Tambov soldatki meeting of March, where the two soldiers who had called it were unable to maintain order in the face of sustained soldatki haranguing and disorderly conduct. In the case of Kazan, soldatki participation in the Soviet resulted in the Soviet losing its own decorum, rather than the soldatki gaining any. The plight of the Kazan soldatki was a real public issue; while their marches and noisy participation in meetings no doubt contributed to a prominent public profile, the effect was redoubled by the Soviet's willingness to organize a range of public collections and charitable fund raising events on behalf of the soldatki. For example, a concert lottery was held on the 28 May, to be followed by a funfair (narodnoe gulian'e), with all funds raised going to the

62. Ibid., no. 31, I8 May I9I7, p. 3.

63. Ibid., no. 34, 2 Ist May 1917, p. 4.

64. Ibid., no. 34, 2 Ist May 1917, p. 4. 
soldatki. ${ }^{65}$ Such events were regular features in the town's public calendar. One can reflect that such public events were, however, a double-edged sword for the Soviet. While they may well have been effective in collecting funds, and in publicly demonstrating that the Soviet was active on behalf of soldatki, they also highlighted the women's continued demands, and the inability of the Soviet effectively to meet these demands.

\section{RESPONSES TO SOLDATKI GRIEVANCES}

The activism of Kazan soldatki proved to be highly effective in winning them a prominent public profile, and real concessions. The plight of soldatki was among the most persistent themes covered in the Kazan military district's newspaper. ${ }^{66}$ The soldatki union was granted use of the Zhuravlev building, situated within the Kremlin, as an office, ${ }^{67}$ and in August was provided with a house to operate as a hostel to house those soldatki with emergency housing needs. Guberniia and uezd zemstva were petitioned to set up cheap cafes for soldatki, and to take other measures to provide for needy soldatki. The town administration was commissioned to satisfy soldatki with firewood, and soldatki were given representation in the Soviet, and on provisions and accommodation commissions. ${ }^{68}$ Seven cheap cafes were established around Kazan town itself to satisfy soldatki needs. These cafes were forced to close in September, however, as a result of: "difficulties with the provisions situation, which made it more and more difficult to satisfy the lunchers, and in connection with the accusations of the soldatki, who were not satisfied with these lunches". ${ }^{69}$

The prominence of soldatki in Kazan was particularly notable, but was to some extent mirrored by the attention given to soldatki issues by resolutions of almost all local government organizations in Nizhnii Novgorod and Tambov as well, from the village skhod and volost committees, up to the guberniia commissar. The plight of soldatki was widely acknowledged, and a range of measures proposed for their relief, including prioritizing soldatki in receiving rented landowners' property, ${ }^{70}$

65. Ibid., no. 35, 24 May 1917, p. I.

66. Izvestiia Kazanskago voenno-okruzhnago komiteta. Ezhednevnaia politicheskaia gazeta. I surveyed issues of this paper for the month of June.

67. Kazanskaia rabochaia gazeta, no. 84 , 29 July 1917, p. 3.

68. Ibid., no. 34, 2I May I917, p. 4.

69. Ibid., no. I24, I3 September I917, p. 3.

70. Izvestiia Tambovskago soveta rabochikh, soldatskikh i krestianianikh deputatov, no. I 36, 2 I September 1917, pp. I-2; from report on the guberniia peasants' meeting, I9 September. In Tambov, where there was land hunger, this prioritization is significant. See also NART, f. 983 , op. I, d. 23, p. II6; from the Kazan guberniia Soviet of peasants' deputies to Il'inskii volost committee, 4 July i917. 
providing assistance in field work, ${ }^{71}$ free or cheap firewood, ${ }^{72}$ and preventing their eviction from rented accommodation..$^{73}$ The importance attributed by local government to the satisfaction of soldatki demands is apparent, and indicates the success of the soldatki in pressing their case.

The ways in which the administration represented the soldatki and their plight gives some indication of their public image. Soviet and provisional government bodies alike employed the language of the battlefield, as the soldatki themselves did, in their attempts to raise public support for the soldatki. A common refrain was that it was society's responsibility to protect the families of those men who shed their blood for the motherland. A direct connection was made between the blood sacrifice made by the soldiers, and the need for people to reciprocate in kind, and thus to acknowledge their sacrifice. In a big advertisement appealing for help for the soldatki, run by the Cultural Enlightenment Committee of the Soviet of soldiers and workers' deputies, it was repeatedly asked: "What will we say to the soldiers suffering in the trenches about the hunger and suffering of their women and children?" 74

This language is important in understanding the prominent role played by symbolism. The complexities of the soldatki position were painted over by the broad brushstrokes of national sacrifice and salvation. The necessary suffering of the men in the trenches was mirrored by the perceivably avoidable suffering of their women and children. The sufferings of soldatki contributed to the overall impression of a nation mobilized, a nation in deathly struggle. Alongside these appeals to patriotic duty, the guberniia administration and the press perpetuated "poor victim" stereotypes of soldatki.75 In the context of 1917, this can be regarded as an implicit attempt to depoliticize the soldatki agenda.

7I. GANO, f. I 887, op. I, d. I7, pp. 27-28; journal of the extraordinary meeting of Arzamasskii uezd zemstvo, I2 April I917; p. 65 (from the resolutions of the first Povolzhe oblast meeting of uezd, town and guberniia ECs, 30 May 1917); NART, f. 983, op. I, d. 23, p. 82; from the Kazan Soviet of peasants' deputies to the Administration of Land Affairs and State Property, June 1917, about the allotment of state horses for the needs of soldiers' families in fieldwork.

72. GANO, f. I887, op. I, d. 2, p. I I, from the meeting of representatives of guberniia and uezd executive committees and the guberniia and uezd commissars, 23-25 May I917; GANO, f. I 887, op. I, d. 8, p. 32, from meeting of Nizhegorodskaia Guberniia executive committee, 24 April I917; NART, f. 983 , op. I, d. I7, p. I 2; from the protocol of the meeting of Musliuminskii volost Committee of Public Safety, I4 May i917.

73. GANO, f. I887, op. I, d. 8, p. 36; from meeting of Nizhegorodskaia guberniia executive committee, I May i917; based on report of Naletov (who was also president of the Soviet of workers' and soldiers' deputies) on the question of regularization of accommodation for soldatki.

74. Kazanskaia rabochaia gazeta, no. 35, 24 May 1917, p. I.

75. For discussion of the "poor soldatka" stereotype in the pre-revolutionary period, see Pyle, "Village Social Relations", pp. I98-217. There was also a need to counter the strongly rooted representation of soldatki as unrespectable members of the population, not least because of their associations with prostitution. For an example of the soldatka as a rough, abusive woman, see 
Sympathy offered in the democratic press to these "poor, illiterate women" implied or stated directly that the soldatki were a wholly unconscious group, who operated only on basic instinct. Soldatki were routinely mentioned along with the poor, refugees, and destitute. ${ }^{76}$ By classifying the state of soldatki as deserving of charity, soldatki demands were depoliticized. To make specific comparisons, all democratic organizations supported without question the implementation of an eight-hour working day as the right of a working man. The right of soldiers to receive polite treatments from their seniors was upheld as due treatment for citizens and comrades. Soldatki demanded as their citizens' rights support from the state to maintain a tolerable standard of living. Though it was practical difficulties that prevented the administration from fulfilling this demand, they did not portray soldatki as equal citizens, but as subjects for pity and for charity. This reflects the way in which the (exclusively male) local government leaders and journalists refused to recognize soldatki as a political force in their own right. This depoliticization echoes the attitudes shown by communist party officials towards peasant women's protests during collectivization..$^{77}$

The soldatki movement did not self consciously identify itself as "political"; that is, it did not take up the programme of a political party, or try to present itself as a political organization in the way that other interest groups did. $^{78}$ None of the sources mention specific links between soldatki and political parties. The intransigent soldatki had potential affinity with the Bolshevik movement, but though they sometimes shared common ground in 1917, the Bolsheviks were little more than travelling companions with the soldatki. ${ }^{79}$ There was an appeal published in a Kazan Bolshevik-controlled newspaper in May to join the soldatki union. ${ }^{80}$ It is a fair assumption that soldatki support for the Bolsheviks probably related to the dynamic of heightened Bolshevik support among other social groups in the latter part of I917. A summary of reports at the Tambov

S.A. Smith, "The Social Meanings of Swearing: Workers and Bad Language in Late Imperial and Early Soviet Russia", Past and Present, I60 (1986), p. I77.

76. See for example, Izvestiia Kazanskago guberniia soveta krestianskikh deputatov, no. 4, 20 July 1917, p. 3: appeal from member of the EC of the Kazan guberniia Soviet of peasants' deputies, Sukhanov, in which he asked that help be offered to "the poor and soldatki".

77. Viola, "Bab'i bunty and Peasants Women's Protest", p. 23.

78. In Kazan, for example, the town employees complained that there was not a single town employee in any of the other lists standing for the town Duma elections, so stood their own list of candidates (as reported in Kazanskaia rabochaia gazeta, no. 132, 23 September 1917, p. 3). In the Duma elections of 8 October, they received 422 votes, which was enough to win them a seat. 79. Farnsworth suggests that in the I920s soldatki were most likely to be receptive to Bolshevik party activists, and most likely to attend meetings; see B. Farnsworth, "Village Women Experience the Revolutions", in Gleason, Kenez, and Stites, Bolshevik Culture: Experiment and Order in the Russian Revolution, p. 249.

80. Rabochii, no. I4, 25 (I2) May I9I7. 
guberniia peasant meeting on 18 November confirms that soldatki on the whole supported the Bolsheviks, but suggested that this support was predicated solely on the desire to see an end to the war:

From the reports it was clear that Bolshevism, as an ideological tendency, had not actually penetrated the peasant midst. Its exponents in the villages were predominantly soldiers from the rear, the majority of whom were ignorant people who knew neither the programme of Bolshevism or of any other programme [...] The security of their success lay solely, as everywhere, in their promise of rapid peace. Bolshevik supporters were found only among soldatki, interested in rapid peace and thinking in their darkness, that Bolsheviks were able to give it to the people $[\ldots]{ }^{81}$

The issue of the war was the one that most surely developed soldatki grievances and actions from local demands for satisfaction of material wants to national concerns. If the soldatki made specific association between their grievous material condition and the war, which widowed or beggared them, their complaints could take on a specifically political bent. There is, however, no evidence from the guberniias considered that soldatki organizations addressed these national concerns in any coherent way. An unnamed Soviet delegate, ${ }^{82}$ reporting on a public meeting of the Kazan Soviet of workers' and soldiers' deputies on I 8 May 1917, which discussed the soldatki question, implied that the soldatki were unknowing vehicles for counter-revolution and anarchy, and that their support for Bolshevik resolutions was a reflection of their "dark unconsciousness" ${ }^{83}$ Notions of "darkness", usually implying ignorance, illiteracy, and lack of culture, were symptomatically applied to the rural population by its intelligentsia observers, and were often particularly directed towards women. ${ }^{84}$ Such language tells us more about the commentator's own fear and ignorance of unfamiliar or unwelcome societal norms and trends than about the allegedly "dark" subjects. ${ }^{85}$ A Bolshevik commentator in the paper Rabochii quite rightly challenged this unnamed author and asked what constituted anarchism. By the definition presented by the Soviet delegate, anarchism was constituted by demands for bread and a conclusion to the war.

81. Izvestiia Tambovskogo soveta rabochikh, krestianskikh i soldatskikh deputatov, no. I62, 2 I November 1917, p. I

82. He was almost certainly a Menshevik, based on the political sympathies generally expressed by this paper.

83. Kazanskaia rabochaia gazeta, no. 34, 21 May I917, p. 4.

84. The word $b a b a$, a colloquial expression meaning "woman" and often referring specifically to rural women, had just such connotations of ignorance, irrationality, and hysteria. (See Viola, "Bab'i bunty and Peasants Women's Protest", p. 23.)

85. See particularly Cathy A. Frierson, Representations of Rural People in Late NineteenthCentury Russia (Oxford, I993), esp. pp. 32-127. 


\section{CONCLUSIONS}

This study of the soldatki movement forces us to reconsider our categorizations of "political" behaviour. Soldatki themselves may not have been self-consciously political, in that they did not often take on party-political identities. They were not generally recognized by the press and political activists as political actors, but as "dark" forces, responding to their material needs. Their insistence to have their needs met, their presentation of grievances in collective and concerted forms, and their direct participation in the peripheries of power, however, necessitates that their protest be considered political. Soldatki demands reflected a broader crisis for the moderate leadership of the Soviets. From the outset of revolution, but particularly from August onwards, the Soviets were faced with direct challenges from their constituents, who demanded that they pursue more radical policy, most particularly demanding a split with the provisional government on the war issue, and greater control over the provisions crisis. ${ }^{86}$ The results of this crisis of power varied from region to region. In Nizhnii Novgorod, moderates retained control of the Soviets until a re-election was forced on them by the Bolsheviks on 30 October 1917. In Kazan, on the other hand, the Bolsheviks formed the strongest single group even in September, and the leftist tendencies of the SR group there meant that the Soviet was dominated by a left SR/Bolshevik alliance. ${ }^{87}$

Three key areas addressed by this study have broader implications for our understanding of i917. Firstly, soldatki are a valuable exemplar of female participation in revolutionary politics. Soldatki have been marginalized in the historiography of 1917, and recognizing their importance as political actors realigns the picture of revolution away from something defined and directed by male workers and soldiers. While soldatki, along with all women, were on the periphery of formal power structures in I917, they organized themselves and placed significant pressure on these formal power structures. They also developed a prominent public profile. Secondly, the continued and escalated demands of soldatki show how the political revolution of February I9I7 dramatically heightened popular expectations of what government could deliver, but correspondingly worsened the economic and administrative problems Russia faced. This was an explosive combination, which offers some insight into the

86. Mike Hickey clearly delineates the progressive downturn in the fortunes of the Smolensk moderate socialists in the context of the heightened radicalism of I917. M.C. Hickey, "The Rise and Fall of Smolensk's Moderate Socialists: The Politics of Class and the Rhetoric of Crisis in 1917”, in D.J. Raleigh (ed.), Provincial Landscapes: Local Dimensions of Soviet Power, 19171953, (Pittsburgh, PA, 2001), pp. 14-35.

87. See Kazanskaia rabochaia gazeta, no. I35, 28 September I917, p. 3. Report of the re-election of the Central Executive Committee of the Soviet of workers' and soldiers' deputies. (Of the 933 members of the combined Soviets, 27I were SR, I90 SD Menshevik and 37I SD Bolshevik.) 
Bolsheviks' growing support in I917. The glimmering promise of a better future through political participation seemed to be a chimera, as conditions worsened despite the proliferation of representative government. Finally, the nature of the directly democratic Soviets, and the problem of where their power and authority really lay, is brought into relief. The Soviets' popular image as the body representing all toiling and impoverished people placed a massive burden of expectation on them. Their requirement to be responsive to national concerns, however, along with the pressure laid upon them by Russia's financial crisis, left them in an ambiguous position, whereby they were practically unable to satisfy the demands laid on them by their constituents. Soldatki rejected the leadership of both provisional government bodies and the Soviets, leaving them as political "loose cannon". This contributed to the sense of political crisis which pervaded the latter months of 1917. 